\title{
Hydrocarbon Geochemical Characteristics and Depositional Environment of Tertiary Tar Sand from Ondo, SW Nigeria.
}

\author{
Uche M. Uzoegbu ${ }^{1}$, Maureen O. Agbadamashi ${ }^{2}$ and Chukwudi Ugbome ${ }^{2}$ \\ ${ }^{I}$ Department of Geology, College of Physical and Applied Sciences, Michael Okpara University of Agriculture, \\ Umudike, P.M.B 7267, Umuahia, Abia State, Nigeria. \\ (+234) 08030715958 \\ ${ }^{2,3}$ Department of Geology, Faculty of Sciences, University of Port Harcourt,P. M. B. 5323, Port Harcourt, \\ Rivers State, Nigeria.
}

\begin{abstract}
In the Dahomey Basin, western Nigeria, tar sand occurs in alternation with sand, sand, shale, carbonate, silstone and clays in transgressive deposits of Cretaceous-Tertiary age. The thickness of tar sand seams drilled during the study varies between 10 and $15 \mathrm{~m}$ and it even exposed to the surface. Organic geochemical characteristics of the tar sand were evaluated using TOC, pyrolysis and GC analyses. The Ondo tar sand is characterized by very high TOC contents (5.53-74.40 wt\%), Hydrogen Index $(\mathrm{HI}=519-796 \mathrm{mg}$ $\mathrm{HC} / \mathrm{g}$ TOC) and very low Oxygen Index $(\mathrm{OI}=1-11 \mathrm{mg} \mathrm{CO} / \mathrm{g}$ TOC) values. Organic matter in the studied tar sand is of Type II kerogen and shows S2/S3 ratio values between 47.11 and 301.63 and low Tmax $\left(428-439{ }^{\circ} \mathrm{C}\right.$ ) and PI (0.18-0.36) values. Gas chromatographic analyses of the bitumen extract show bimodal and unimodal n-alkane distributions. CPI varies from 0.24 to 1.00 in IREN and 0.16 to 4.13 in LODA showing that LODA attended higher level of maturation as compared to IREN. Furthermore, indicated that LODA organic matter was deposited in a deeper environment than IREN or closer to heat source. Pr/Ph ratio (0.78-3.31; 0.87-2.33), Long/Short ratio (0.72-0.77; 1.00-1.60), OEP (0.02-0.68; 0.33-0.42), Pr/n- $C_{17}(0.84-2.25 ; 0.19-1.61), P h / n-C_{18}$ $(0.04-3.73 ; 1.00-1.67)$ and $C_{31} /\left(C_{31}+C_{29}\right)(1.00-3.40 ; 1.20-3.60)$ revealed contributions of marine to terrestrially source of organic matter and dysoxic to marine as depositional environment.
\end{abstract}

Keywords: Tar sand, TOC, Tmax, production Index, depositional environment, Dahomey Basin, Nigeria.

\section{Introduction}

Nigeria's current national petroleum reserves asset (proven) is put at 35 billion barrels of oil. Gas reserve on the other hand has been estimated to be about 170 trillion standard cubic feet. Current production of oil and gas in Nigeria comes entirely from the Niger Delta onshore and Offshore. The search for hydrocarbons in the Cretaceous source rocks in the Nigerian in land sedimentary basins has been a major task for many decades now. The efforts were to bust the oil and gas exploration and production activities and also adequately tap the natural resources in the country. Geosciences research in the aspects of hydrocarbon search in the Nigeria sector of the Dahomey basin has been so few for many years. In the last decade, there have been considerable interest and geosciences researches in the aspects of hydrocarbon search in the basin. Recent exploration and prospect re-evaluation efforts in the Nigeria segment of the basin have been encouraged following the oil discovery and production in the neighboring Benin republic sector west of the basin and the social unrest in the prolific Niger Delta, east of the basin [Adekeye and Akande, 2010].

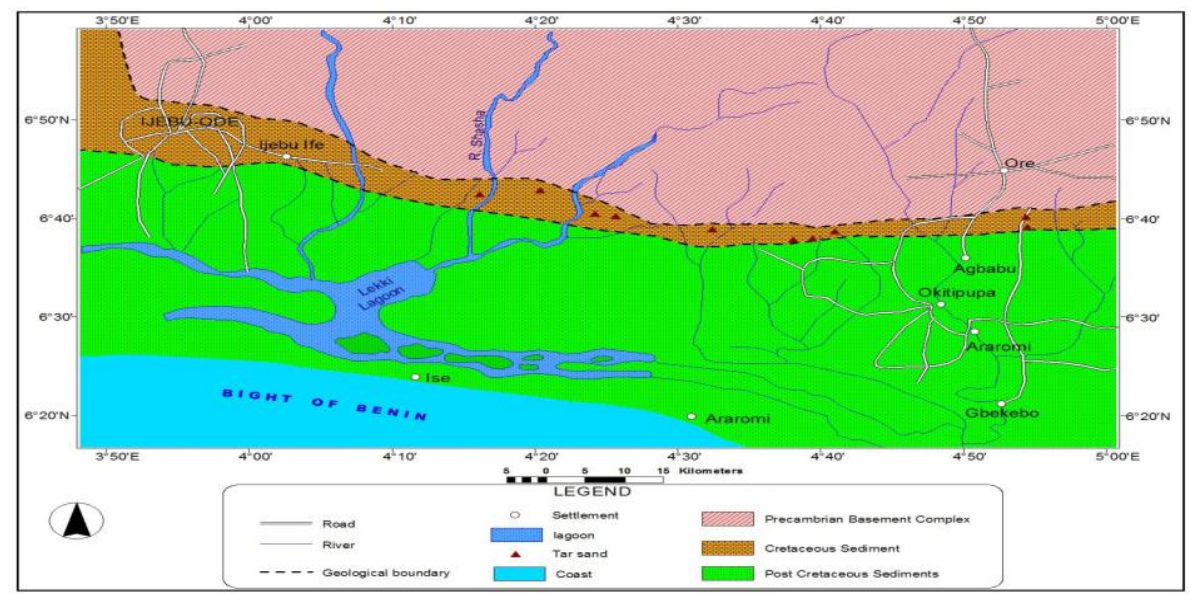

Fig. 1: Geology of the tarsands belt showing the outcrops [Adapted from Ako, 2003]. 
Nigeria's reserve is estimated to be about 30-40 billion barrels with potential recovery of $3654 \times$ 10bbls [Adegoke et al., 1991]. Of the estimated 30-40 billion barrels of oil sands, Ondo State probably has more than $45 \%$ of Nigeria's reserve [Tetede, 2006]. However, this enormous reserve of oil sands in Nigeria is yet to be exploited as can be seen in Fig. 1 which indicates that only about 30 billion barrels of conventional oil reserves have been exploited, while the unconventional resources have not been exploited at all. Seepages and outcrops play an important role in the exploration of sedimentary basin or area. A look at exploration history of most important oil fields of the world prove conclusively that oil seeps gives the first clue to the presence of oil reservoir in the subsurface. Seeps occur whenever a permeable pathway leads to the surface from leaking petroleum reservoir. Tar sands seepages discovered in the villages of Agbabu, Illubinrin and roads along Irene and Loda (Fig. 2) Ondo State served as an indication that they are from a reservoir in the subsurface [Akinyemi et al., 2013]. At these areas, outcrops were observed and representative samples were systematically collected.

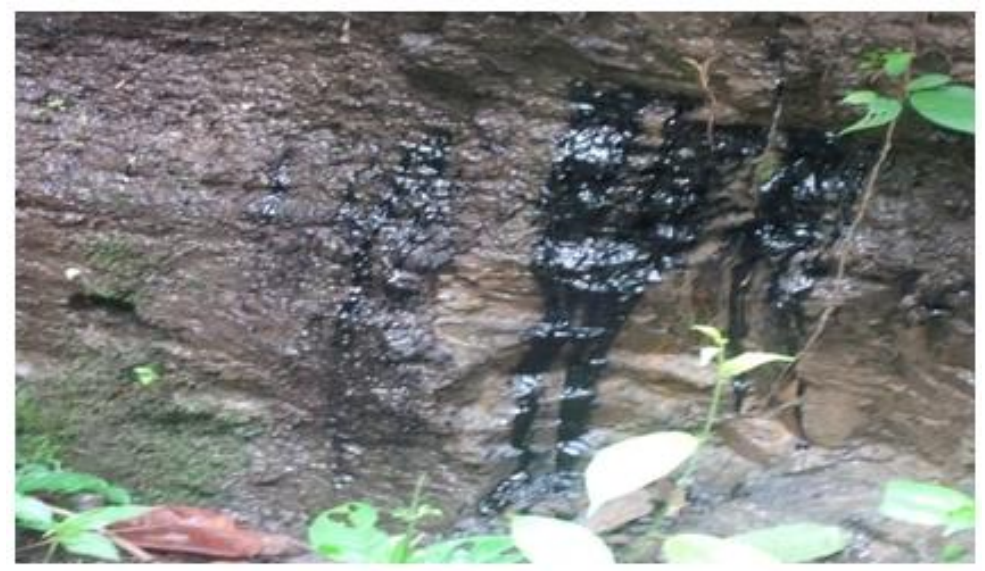

Fig. 2: Tarsands outcrop at Agbabu, Ondo State. Magnification X 100

Tar sand and tar deposits all originates from conventional hydrocarbon sources, when organic matter in the source rock is matured, the rock matrix starts to generate oil, the generated oil is expelled and eventually commences primary migration. After which it finds its way into a carrier bed and into secondary migration. It could get into a trap which provides the configuration on which the accumulation increases. However, where the trap was not in place as at the time of emplacement of the oil in the reservoir, the migrating oil will migrate out most possible into the surfaces where it's known as seeps. Where the migration continues impregnated into sands or sandstones, it's known as tar sand or oil sand [Head et al., 2003]. Fig. 3 shows an idealized foreland basin petroleum system, it also shows the reservoir grading into shallow depth where the oil migrates to and remains exposed to oxidation and biodegradation with increasing loss of lighter molecular weight ends of the hydrocarbon, the heavier ends are left behind which remains rich in asphaltene.

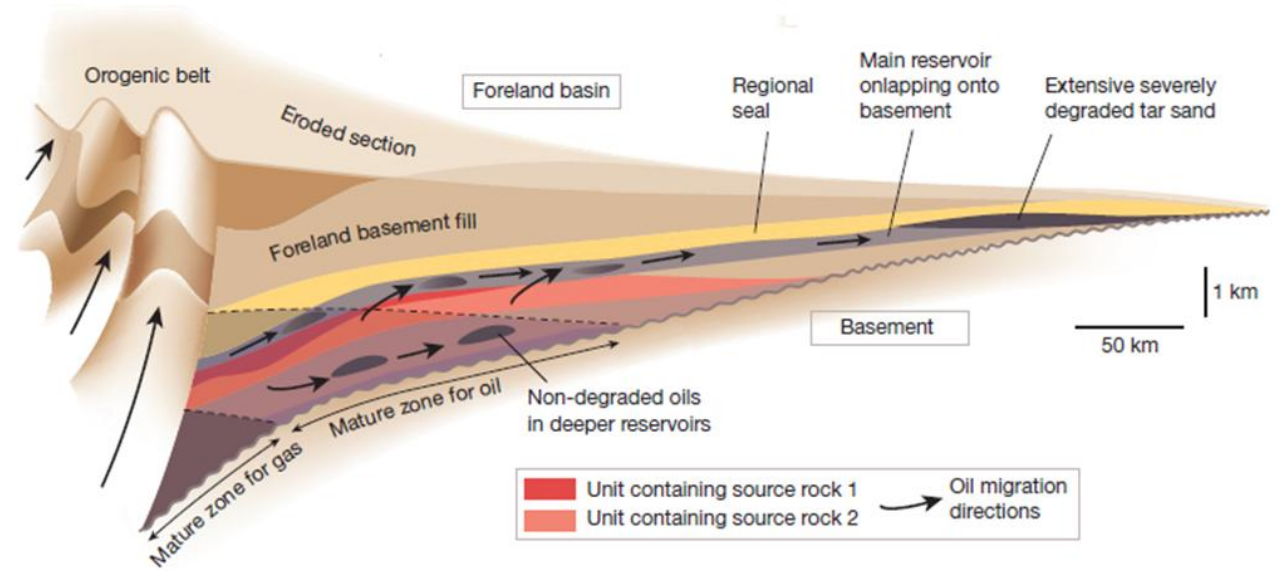

Fig. 3. An idealized foreland basin petroleum system, showing oil migrating into more shallow depths where there is no effective seals and it become biodegraded and exists as tar sands [Head et al, 2003].

The aim of this research work is to determine the quality, maturity variation, total organic carbon variation, source and environment of deposition of the organic matter from the tar sands. 


\section{Geologic Setting}

The study area lies within latitude $06^{\circ} 38^{\prime}-06^{\circ} 40^{\prime} \mathrm{N}$ and longitude $04^{\circ} 34^{\prime} \mathrm{E}-04^{\circ} 37^{\prime} \mathrm{E}$, and falls within the eastern Dahomey Basin (Fig. 4). Samples for this study were obtained from five different locations where there are outcrops of the tarsands and where there exist live seepage from the tar sand. Samples were obtained from Agbabu, Ilubinrin and roads along Irene and Loda all around Ore Ondo State shown in figure 4. Agbabu is well known as a place were open pit mining of Nigerian tar sand deposit occurs.

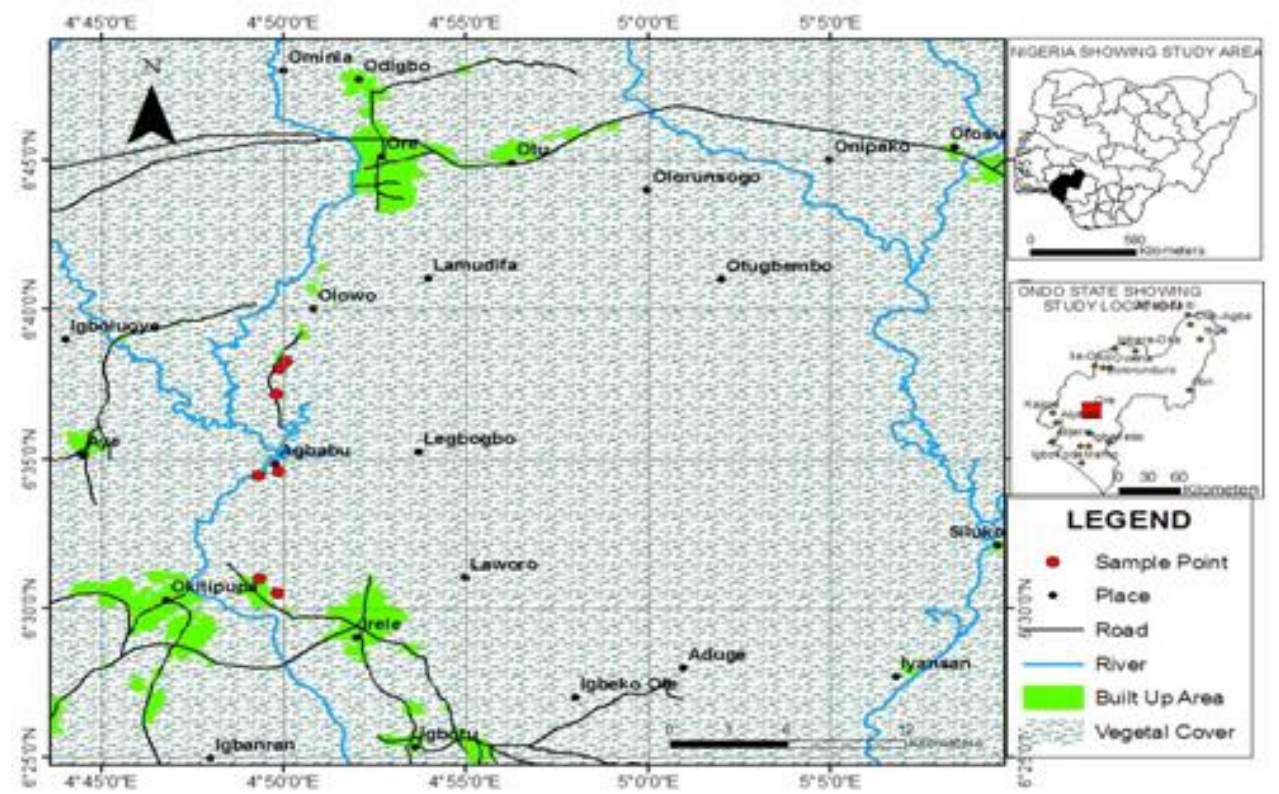

Fig. 4: A physiographic map showing location of sample collections [After Ndukwe et al., 2015].

Akintola et al. (2013), has highlighted origin/occurrence of tar sand deposit in Nigeria, this subject has several schools of thought since its discovery. One of these suggests that petroleum hydrocarbon could have migrated from Niger Delta Basin via fractures, faults or extensive and interconnected sand bodies into Eastern portion of the Dahomey Basin. The stratigraphy of the Dahomey basin is shown in Fig. 5. The formations of interest from the oldest to the youngest are Ise, Afowo and Araromi formation. Ise formation unconformably overlies the basement complex of South Western Nigeria, consisting of conglomerates and grits at the base which is in turn overlain by coarse to medium grained sands with interbeded kaolinite. An age range of Neocomian-Albian is assigned to this formation based on paleontological assemblages. Afowo formation overlies the Ise formation, and composed of coarse to medium grained sandstone with variable but thick interbedded shale, siltstone and claystone. The sandy facies are tar bearing while shales are organic-rich. Using palynological assemblage, a Turonian age is assigned to the lower part of this formation, while the upper part ranges into Maastrichtian [Akinmosin et al., 2012].

\begin{tabular}{|c|c|c|c|c|c|}
\hline \multirow[t]{8}{*}{$\begin{array}{l}\text { Generalized } \\
\text { Lithology }\end{array}$} & \multicolumn{2}{|l|}{ Formation } & Age & $\begin{array}{l}\text { Thickness } \\
\text { (feet) }\end{array}$ & Comments \\
\hline & $\begin{array}{l}\text { Benin Fm.; } \\
\text { Coastal Plains } \\
\text { Sands } \\
\end{array}$ & \multirow{3}{*}{ 带 } & $\begin{array}{c}\text { Pleistocene - } \\
\text { Oligocene }\end{array}$ & $\begin{array}{l}0- \\
1600\end{array}$ & coastal-plain clastics \\
\hline & $\begin{array}{c}\text { Oshosun - llaro - } \\
\text { Ameki Fms. }\end{array}$ & & Eocene & $\begin{array}{l}200- \\
1000\end{array}$ & $\begin{array}{l}\text { fluvial and marine } \\
\text { sands and clays }\end{array}$ \\
\hline & Ewekoro Fm. & & Paleocene & $\begin{array}{l}400- \\
1000\end{array}$ & $\begin{array}{c}\text { marine shale. } \\
\text { limestone }\end{array}$ \\
\hline & $\begin{array}{l}\text { Araromi Fm. } \\
\text { Abeokuta Fm. }\end{array}$ & \multirow{3}{*}{ 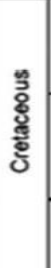 } & Maastrichtian & $\begin{array}{l}500- \\
1000\end{array}$ & $\begin{array}{c}\text { coastal sand, shale: } \\
\text { marine shale }\end{array}$ \\
\hline & $\begin{array}{l}\text { Afowo Fm. } \\
\text { Turonian Sst. } \\
\text { Albian Sst. }\end{array}$ & & $\underset{\text { Aptian }}{\text { Campanian - }}$ & $\begin{array}{l}0- \\
800\end{array}$ & $\begin{array}{l}\text { marine sandstone, } \\
\text { shale, limestone }\end{array}$ \\
\hline & Ise Fm. & & $\begin{array}{l}\text { Barremian - } \\
\text { Neocomian }\end{array}$ & $\underset{6000+}{0-}$ & $\begin{array}{l}\text { continental and } \\
\text { lacustrine rift-basin fill }\end{array}$ \\
\hline & $\begin{array}{c}\text { crystalline } \\
\text { basement } \\
\text { (undifferentiated) }\end{array}$ & & $\begin{array}{l}\text { Cambrian - } \\
\text { recambrian }\end{array}$ & & $\begin{array}{l}\text { metamorphic and } \\
\text { igneous complex }\end{array}$ \\
\hline
\end{tabular}

Fig. 5: Stratigraphic Column of the Eastern Dahomey Basin [From Akinmosin et al., 2013]. 


\section{Materials And Methods}

Two methods of sample collection were employed within this period. These are the grab and bulk sampling methods. Although the grab method of sampling is not the best for collection of samples for analysis, it was used here to get representative samples from Ondo for tar sand in order to carry out laboratory analyses on a large scale.Chisel, spatula and sample bags were used for the collection of the samples. The samples collected were labeled according to each locality. Care is taken to avoid sampling unwanted sections or contamination in the samples.A total of 9 tar sand samples were collected from tar sand in five locations at Agbabu, Illubinrin and roads along Loda and Irene. The number of samples from any of this locality was based on the accessibility of the sample area and the extent to which the tar sand is development at the outcrop (Plates $\mathrm{A}$ and $\mathrm{B})$.

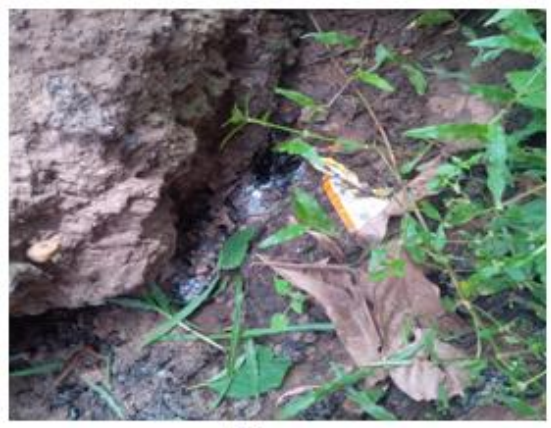

(a)

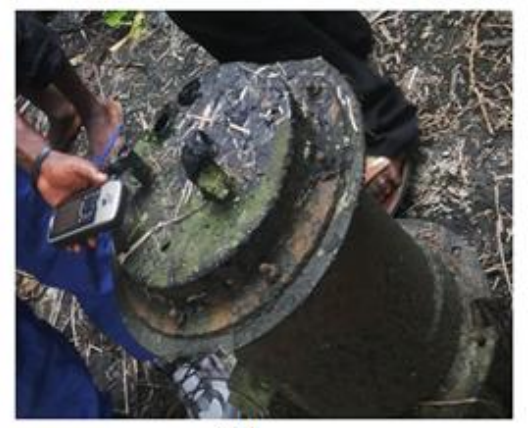

(b)

Plates: Field photograph of tarsand outcrops at Illubinin (a) and b). Showing the drilled wellbore at Agbabu. Magnification X 100.

\section{Samples Preparation}

A total of nine bulk tar sand samples were analysed. For each of these samples, 2 to $3 \mathrm{~g}$ was used for the analyses. The samples were dissolved on a temperature below $40^{\circ} \mathrm{C}$ to remove the dirty and sands on the samples. These dissolved samples were measured in crucibles ready for Rock-Eval analysis.

\section{Rock-Eval 6 Pyrolysis}

A total of nine tar sand samples from Ondo have been subjected to Rock-Eval pyrolysis.

The instrument used was the Rock-Eval 6 Classic $\mathrm{S}_{3}$ that has a programmed heat conducted from $100^{\circ} \mathrm{C}$ to $850^{\circ} \mathrm{C}$ for both the pyrolysis and the oxidation ovens. A mass of $2-3 \mathrm{mg}$ of dissolved tar sand samples were weighed in crucibles with a balance weighing instrument model Sartorius ISO 9001. The weighed samples together with the crucibles were placed in a Rock-Eval 6 machine where the samples were subjected to initial temperature of $100^{\circ} \mathrm{C}$ before it was increased to $300^{\circ} \mathrm{C}$ and finally to the temperature of $850^{\circ} \mathrm{C}$. In between these temperatures, the Tmax, the temperature at maximum rate of pyrolysable $\left(\mathrm{S}_{2}\right)$ hydrocarbon generation, was determined. Also free oil content $\left(\mathrm{S}_{1}\right)$, pyrolysable hydrocarbon content $\left(\mathrm{S}_{2}\right)$, and amount of $\mathrm{CO}_{2}\left(\mathrm{~S}_{3}\right)$ were determined (Fig. 6). During heating at temperatures between 100 to $300^{\circ} \mathrm{C}$ free hydrocarbon $\left(\mathrm{S}_{1}\right)$ is obtained. As cracking of kerogen continued in the furnace at temperature between 400 and $600{ }^{\circ} \mathrm{C}$ residual hydrocarbons potential $\left(\mathrm{S}_{2}\right)$ is obtained. Increase in temperatures from 600 to $850{ }^{\circ} \mathrm{C}$ cause the liberation of $\mathrm{CO}_{2}$ resulting in the determination of $S_{3}$. In between the temperatures of 400 to $600{ }^{\circ} \mathrm{C}$ maximum temperature (Tpeak) is attained leading to the birth line or determining the maturity of an individual sample.
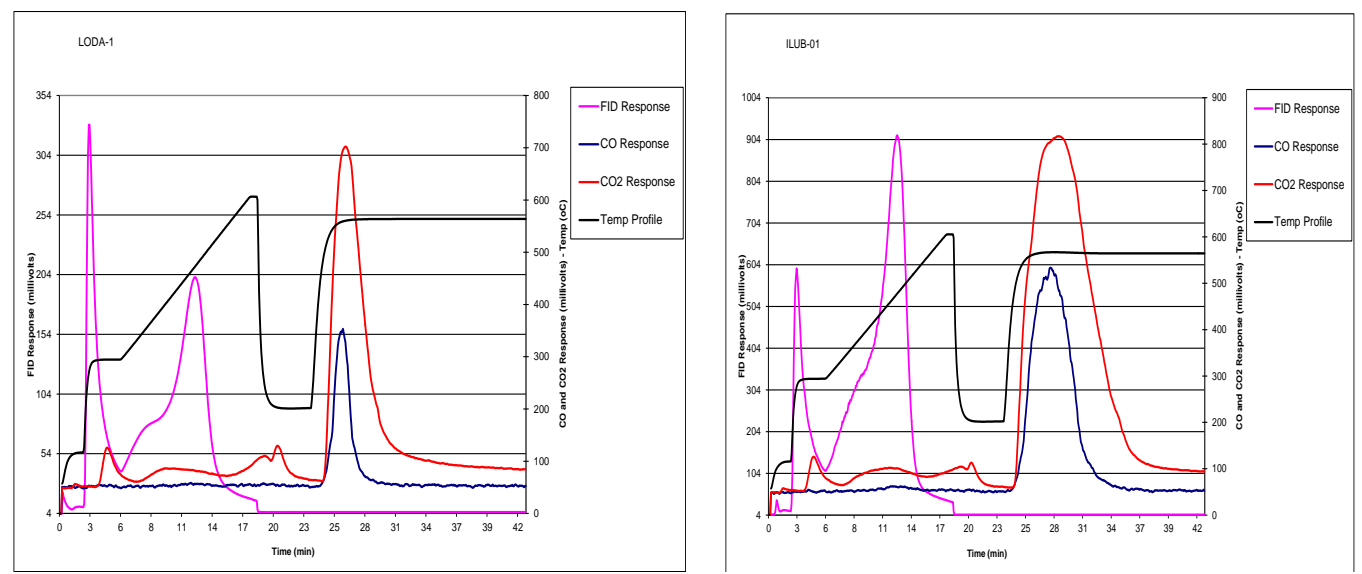

Fig. 6: Programmed pyrolysis result profile showing Loda and Illubinrin samples 


\section{GC-MS Analysis}

The oil sand (3gm) were first dissolved in DCM (dichloromethane) (200mls) to remove the sand, clay which are insoluble in DCM, the solution was decimated separating the sand and clay out. The resultant solution was left in a fume chamber to evaporate, the tar was then dissolve in $200 \mathrm{mls}$ of pentane (AnalaR Grade) while stirring and continued for $1 \mathrm{hr}$. the solution was allowed to cool in a freezer for $2 \mathrm{hrs}$ at $5^{\circ} \mathrm{C}$. The precipitated asphaltene were filtered off washed with cold n-pentane and dried in a dessicators, then weighed and scraped into a sample vials. The obtained asphaltene were then presented for GC-MS analysis for a suite of metals. The metals were mainly the biophiles [Udo et al., 1992]. A 3g of the sample (asphaltene) was subjected to sohxlett extraction using a solvent mixture of acetone, chloroform and methanol $(47: 30: 23 \mathrm{v} / \mathrm{v})$ at $60^{\circ} \mathrm{C}$ for 24 hours to extract the soluble organic matter. The extract was concentrated by evaporation to dryness using a rotating vapour evaporator at $250 \mathrm{mb}$. The extract was transferred to an $8 \mathrm{ml}$ vial using the same solvent mixture and allowed to evaporate to dryness in a vented hood. The dried extract was fractionated by silica gel column chromatography with a column prepared using $2 \mathrm{~g}$ of baker silica gel calcined at $200^{\circ} \mathrm{C}$ for 24 hours to yield six fractions ranging from saturate to polar (Fig.7).

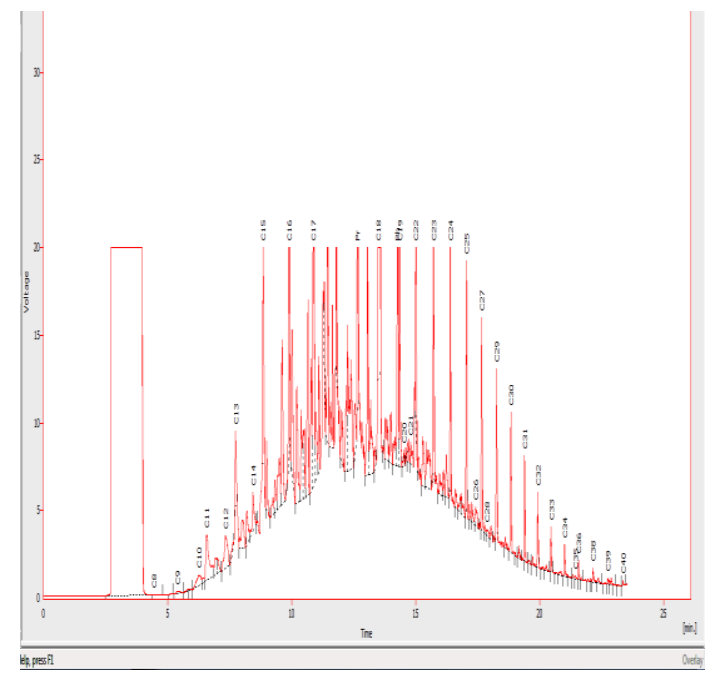

(a)

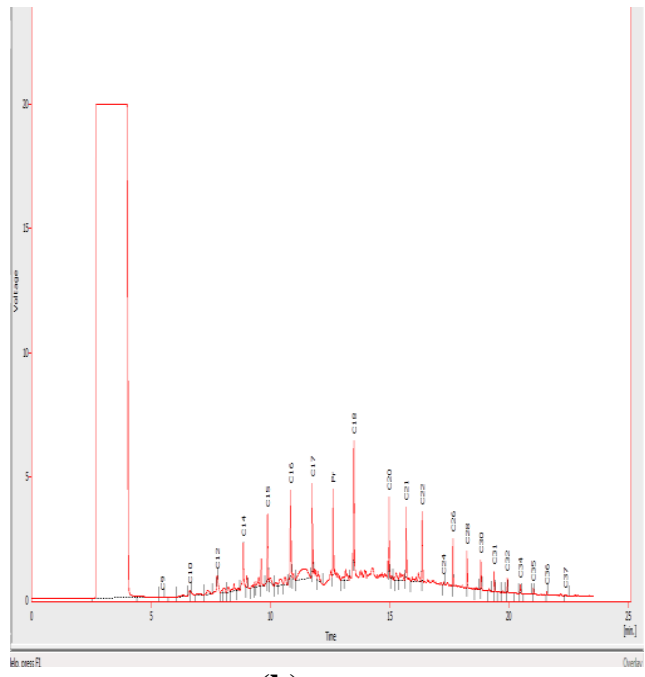

(b)

Fig. 7: Chromatogram finger print of tarsand samples from; a) Loda and b) Illubinrin.

The saturate fraction was subjected to urea adduction to separate isoprenoids from $n$-alkanes and subjected to gas chromatography-mass spectrometry (GC-MS) using a CE 5980 GC coupled to an HP Finnigan $8222 \mathrm{MS}$ held at $80^{\circ} \mathrm{C}$ for three minutes and raised to $310^{\circ} \mathrm{C}$ at $3{ }^{\circ} \mathrm{C} \mathrm{min}{ }^{-1}$ and held isothermally for 10 minutes in order to assess some molecular parameters used in source rock characterization.

\section{Result And Discussions}

Tar sand which are also known as oil sands are not popularly known but have spikes of occurrences compared to the occurrences of petroleum deposited. Tar sands are sedimentary rocks that contain bitumen or heavy oil, and are also known as tar sands or asphaltic sands. Tar sand bitumen and/or heavy oil are formed by low temperature alteration of crude oil, by biodegradation, water washing or light-hydrocarbon volatilization, thus resulting in concentration of high molecular weight hydrocarbons and heteroatomic compounds of resins and asphaltenes. Tar sand often exists at the edge, and within shallow layers of a basin, and may be exposed at the surface by tectonic uplift.

The capacity to generate petroleum depends largely on the chemical composition of this convertible carbon fraction (Lebile kerogen). The TOC measurement is the first screen for quantifying organic richness. TOC values provide only a semi-quantitative scale of petroleum-generating potential. TOC indicates the quantity, but not the quality of organic matter. If this initial screening test demonstrates sufficient organic content, the rock should undergo additional tests to ascertain organic matter quality and maturity.

TOC values ranges from 5.53 to $74.40 \mathrm{wt} \%$ with a mean of $26.85 \mathrm{wt} \%$. Tmax values ranges from $428-439^{\circ} \mathrm{C}$ with a mean value of $433^{\circ} \mathrm{C}$ (Table 1). The pyrograms of tar sand samples is shown in Fig. 6 .

Total organic carbon (TOC) which is the measure of the amount of carbon found in an organic compound is important in the geochemical characterization of ta rsands. $0.5 \mathrm{wt} \%$ of TOC is the minimum value and is considered as the minimum limit for hydrocarbon generation [Tissot and Welte, 1984; Bordenove et al., 1993; Hunt, 1996; Hendrix et al., 1995]. The TOC content of 5.53 to $74.40 \mathrm{wt} \%$ indicates excellent hydrocarbon content in the tar sand samples. This is confirmed by the plot of TOC (wt \%) versus $\mathrm{S}_{2}$ (Figs. 8). On the other 
hand, the plot of $S_{1}$ versus TOC (Fig. 9) is used to discriminate between non-indigenous (allochthonous) and indigenous hydrocarbons (autochthonous). The plots show that the tar sand samples were characterized equally by allochthonous and autochthonous hydrocarbons. This indicates that some oil migrated from another source. TOC is used here as a link to determine variation in source rock quality through expulsion of oil.

Hydrogen index (HI) ranges from 519 to $796 \mathrm{mgHC} / \mathrm{gTOC}$ (Table 1) with an average of 642 $\mathrm{mgHC} / \mathrm{gTOC}$. The average HI from $\mathrm{S}_{2}$ vs. TOC plot [Langford and Blanc-Valleron, 1990] of tar sand samples is $642 \mathrm{mgHC} / \mathrm{gTOC}$ (Fig. 8). The HI vs. OI plots for the samples plotted in the organic matter type I fields (Fig. 10). Tmax vs. HI plot of tar sand samples is shown on Fig. 11. $\mathrm{S}_{2} / \mathrm{S}_{3}$ values range from 47.11 to 301.38 (Table 1). In Table 1, $\mathrm{S}_{1} / \mathrm{TOC}$ values are between 1.73 and 3.15. The production Index (PI) for tar sand samples are between 0.18 and 0.36 . The quality of organic matter (OM) in the tar sand samples was done by using RockEval generated data (HI and Tmax). The tar sand samples plot mainly along the oil prone kerogen

Table 1: Results of Rock-Eval analysis and calculated parameters.

\begin{tabular}{|c|c|c|c|c|c|c|c|c|c|c|c|} 
Sample Name & Lithology & $\begin{array}{c}\text { Tmax } \\
{ }^{\circ} \mathrm{C}\end{array}$ & $\begin{array}{c}\mathrm{S1} \\
\text { (mg/g) }\end{array}$ & $\begin{array}{c}\mathrm{S} 2 \\
(\mathrm{mg} / \mathrm{g})\end{array}$ & $\begin{array}{c}\mathrm{S3} \\
\text { (mg/g) }\end{array}$ & PI & S2/S3 & S1/TOC & TOC\% & HI & 0I \\
\hline \hline IRE-1 & Oil Sands & 429 & 45.37 & 80.87 & 0.72 & 0.36 & 112.32 & 3.15 & 14.42 & 561 & 5 \\
\hline IREN-01 & Oil Sands & 433 & 30.40 & 62.24 & 0.72 & 0.33 & 86.44 & 2.92 & 10.42 & 598 & 7 \\
\hline IREN-02 & Oil Sands & 428 & 13.99 & 28.74 & 0.61 & 0.33 & 47.11 & 2.53 & 5.53 & 519 & 11 \\
\hline IREN-03 & Oil Sands & 436 & 32.15 & 68.95 & 0.23 & 0.32 & 299.78 & 3.03 & 10.62 & 650 & 2 \\
\hline AGBA-01 & Oil Sands & 435 & 110.54 & 338.17 & 3.36 & 0.25 & 100.65 & 2.35 & 47.01 & 719 & 7 \\
\hline AGBA-02 & Oil Sands & 436 & 217.31 & 543.89 & 3.40 & 0.29 & 159.97 & 2.92 & 74.40 & 731 & 1 \\
\hline LODA-1 & Oil Sands & 434 & 42.90 & 105.15 & 1.20 & 0.29 & 87.63 & 2.65 & 16.21 & 649 & 7 \\
\hline LODA-2 & Oil Sands & 430 & 25.61 & 55.50 & 0.99 & 0.32 & 56.06 & 2.58 & 9.93 & 559 & 10 \\
\hline ILUB-01 & Oil Sands & 439 & 91.93 & 422.28 & 1.40 & 0.18 & 301.63 & 1.73 & 53.08 & 796 & 3 \\
\hline
\end{tabular}

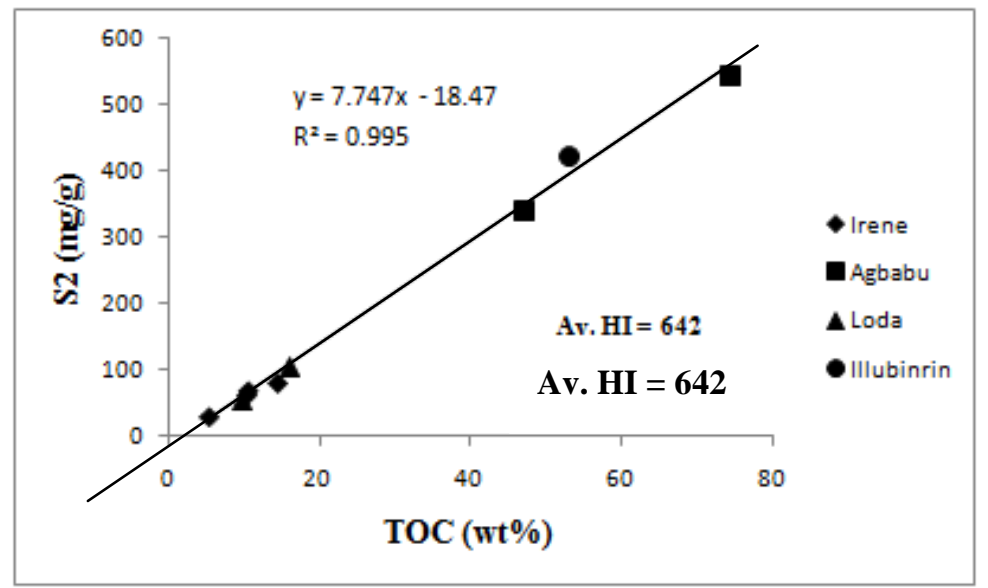

Fig. 8: S2 vs TOC plot of tarsand samples with calculated average hydrogen index (Av. HI and sample name attached).

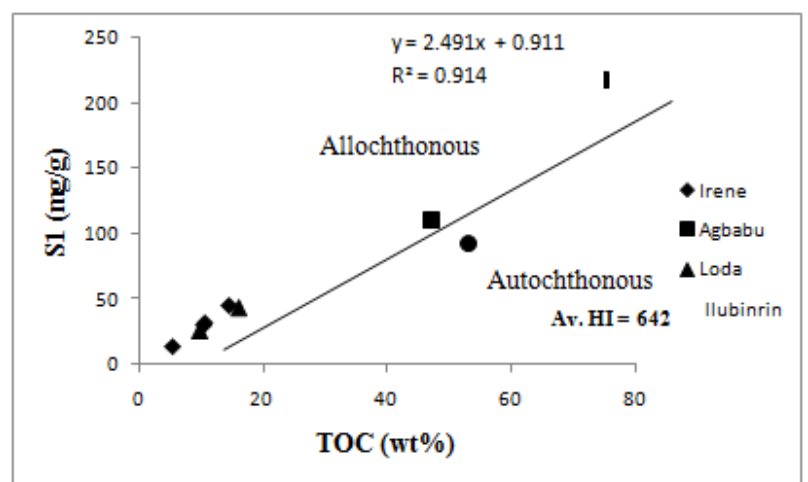

Fig. 9: Diagram of S1/TOC using Ondo tarsand samples for discriminating between non indigenous and indigenous hydrocarbon. 


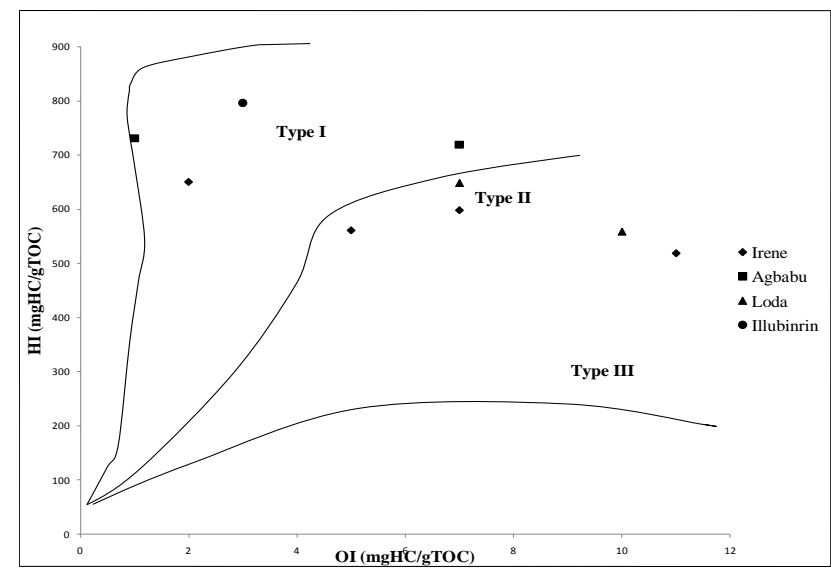

Fig. 10: HI vs. OI plot of tarsand samples from Ondo.

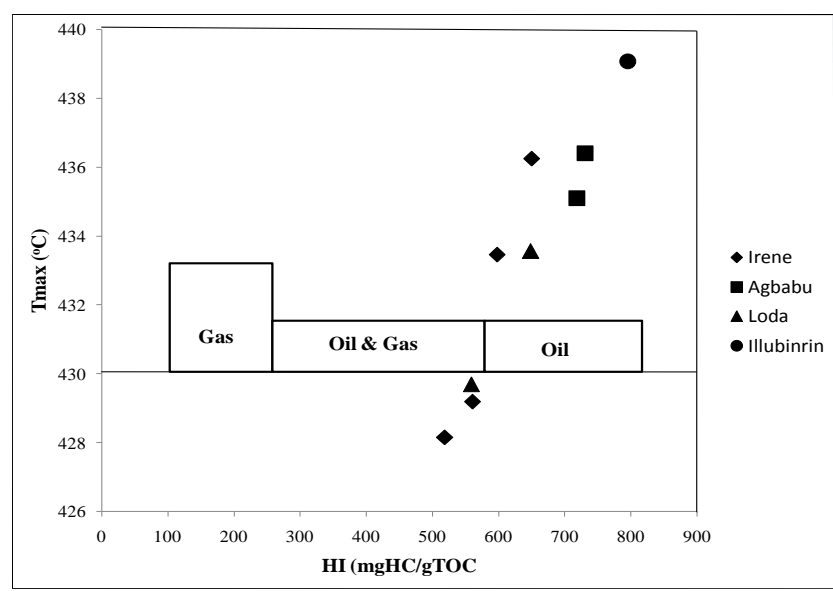

Fig. 11: Tmax vs HI plot of tarsand samples from Ondo.

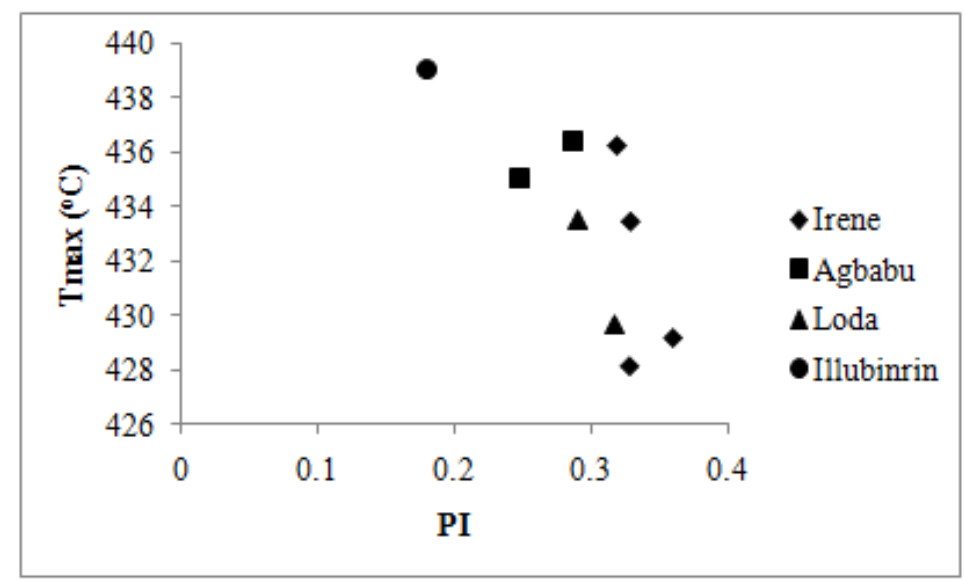

Fig. 12: A plot showing Tmax vs. Production index (PI) of tarsand samples from Ondo.

Evolutionary pathway as indicated by the plot of HI against Tmax. This confirms that a substantial proportion of the OM is of marine origin with oil potential.Waples (1985) used the HI values to differentiate between the types of OM. HI <150 mg/g indicates mainly type III kerogen (Gas prone), Hydrogen indices between 150 and $300 \mathrm{mg} / \mathrm{g}$ indicates that the $\mathrm{OM}$ is oil and gas prone but mainly gas because it contains more type III kerogen than type II kerogen. HI $>300 \mathrm{mg} / \mathrm{g}$ is oil and gas prone but mainly oil because it contains a large amount of type II kerogen than type III kerogen. Kerogen with $\mathrm{HI}>600 \mathrm{mg} / \mathrm{g}$ indicates the presence of type I or type II kerogen and therefore have an excellent hydrocarbon potential (Oil prone). The HI values of tarsand samples indicate the presence of type I or type II kerogen. The plot of S2 vs. TOC plot [Langford and Blanc-Valleron, 1990] in fig. 8 shows that tarsand are characterized by kerogen type I and type II. High HI content in this tarand is probably caused by unusual kind of organism rich in lipids that formed the OM. 
The Tmax values measured during the pyrolysis and the calculated PI values are closely related to thermal history of the OM [Tissot et al., 1984; Waples, 1985]. According to Peters, 1986 and Espitalié et al. (1985), oil generation began at $\mathrm{Tmax} 435-465^{\circ} \mathrm{C}$, and PI between 0.2 and 0.4 , the $\mathrm{OM}$ are in immature stage when Tmax has a value less than $435^{\circ} \mathrm{C}$, and PI less than 0.2 and the gas generation began at Tmax $470{ }^{\circ} \mathrm{C}$, and production index PI more than 0.4. HI versus Tmax [Espitalié et al., 1985] plot (Fig. 11) shows that the tar sand samples plotted in the immature zone of type I kerogen. The plot of Tmax versus PI [Waples, 1985; Peters, 1986] (Fig. 12) shows that the tar sand samples are immature. PI results hovers between 0.18 and 0.36 indicating that the OM has reached the production stage. PI also allowed dissemination of oil when Tmax below threshold affects the OM. Again, Tmax is applied here to determine maturation variation of the OM from the source rock that produced the tar sands.

\section{Environmental Geochemistry}

Low Molecular Weight (LMW) n-alkanes are usually produced by marine biogenic sources while High Molecular Weight (HMW) n-alkanes are usually produced from terrestrial vascular plant. Concentrations of LMW and HMW n-alkanes can be obtained from the following:

$\mathrm{LMW}=$ Sum of concentrations of aliphatic hydrocarbons ranging from $\mathrm{nC}_{10}$ to $\mathrm{nC}_{20}$.

$\mathrm{HMW}=$ Sum of concentrations of aliphatic hydrocarbons range from $\mathrm{nC}_{21}$ to $\mathrm{nC}_{36}$.

Predominantly, lower molecular weight $\mathrm{n}$-alkanes exist in fresh oil while higher plants, marine animals and sedimentary bacteria show higher molecular weight n-alkanes [Pingchang et al., 2013]. Main peaks with carbon numbers greater than $\mathrm{nC}_{20}$ reflect the significant incorporation of higher plant wax and some fungi, whereas those with lower carbon numbers indicate major inputs from microbial activity (algae and bacteria $\mathrm{nC}_{17}, \mathrm{nC}_{18}$ ) or petroleum (diesel exhaust $-\mathrm{nC}_{20}, \mathrm{nC}_{21}$ ). LMW/HMW ratio in $\mathrm{n}$-alkanes in sediments is used to distinguish macrophytes from terrestrial plants [Pingchang et al., 2013]. Values below 1 show natural input from terrestrial biogenic sources while values above 1 show natural input from marine biogenic sources. LMW is predominance in the sample locations. Long Chain Hydrocarbons (LHC) is n-alkanes above $\mathrm{nC}_{20}$ while Short Chain Hydrocarbons ( $\mathrm{SCH})$ are n-alkanes below $\mathrm{nC}_{20}$. LHC/SHC ratio is used to assess the macrophyte/land plant and phytoplankton- dominant trends. Low LHC/SHC values such as 0.21 to 0.80 are dominantly phytoplankton derived. Intermediate values such as 2.38 to 4.33 show a mixture of both input sources. Higher ratios above 4.0 are dominated by terrestrial plant waxes [Pingchang et al., 2013]. It is predominance of long chain over short chain n-alkanes as their values varies from 0.54 to 1.60 with a mean of 0.89 (Table 2) indicating a dominance source of marine organic matter [Guangyou et al., 2013].

The $\mathrm{Pr} / \mathrm{Ph}$ ratios from 0.78 to 3.31 with value of 1.58 in all localities suggest a marine to terrestrial derived material because $\mathrm{Pr} / \mathrm{Ph}$ is found mainly from the phytol portion of photosynthetic plant chlorophyll [Didyk et al., 1978; IIIich, 1983]. Value of OEP varies from 0.02 to 0.68 with mean of 0.36 (Table 2).

These values of OEP for immature higher plant contributions are often >1.0 but approach 1.0 with increasing maturity [Bray and Evans, 1961; Didyk et al., 1978]. The CPI results gotten from tar sand could be said that majority of the terrestrial material is probably transported by fluvial processes and deposited under marginal to marine environments [Bird et al., 1995; Obaje et al., 2004] which contribute to the marine source of OM in the Ondo samples.

Table 2: Showing n-Alkanes, Isoprenoids distribution and ratios from GC of tar sand samples from Ondo, Dahomey Basin.

\begin{tabular}{|c|c|c|c|c|c|c|c|c|c|c|}
\hline Sample & Locality & Lithology & Basin & CPI & $\mathrm{Pr} / \mathrm{Ph}$ & Long/Short & OЕP & $\mathrm{Pr} /$ & $\mathrm{Ph} /$ & C31/ \\
\hline Name & & & & & Ratio & Ratio & & n-C17 & n-C18 & $(\mathrm{C} 31+\mathrm{C} 29)$ \\
\hline AGBA-01 & Agbagu & Tarsand & Dahomey & 2.12 & nd & 0.72 & 0.68 & 0.84 & nd & 1.00 \\
\hline AGBA- 02 & $"$ & $"$ & " & 1.25 & 1.13 & 0.77 & 0.02 & 1.50 & 1.60 & 1.10 \\
\hline ILUB-01 & Illubinrin & $"$ & $"$ & 1.85 & 0.87 & 0.82 & 0.41 & 2.25 & 1.00 & 3.40 \\
\hline IRE-01 & Irele Road & $"$ & $"$ & 2.11 & 0.78 & 1.60 & 0.41 & 0.19 & 1.67 & 3.30 \\
\hline IREN-02 & " & $"$ & $"$ & 0.24 & 1.09 & 0.54 & 0.57 & 0.75 & 3.73 & 1.00 \\
\hline IREN-03 & $"$ & $"$ & $"$ & 1.00 & 3.31 & 0.98 & 0.06 & 1.61 & 0.80 & 1.20 \\
\hline LODA-01 & Loda Road & $"$ & $"$ & 4.13 & 2.33 & 1.00 & 0.42 & 0.10 & 0.04 & 3.60 \\
\hline LODA-02 & $"$ & $"$ & $"$ & 0.16 & nd & 0.66 & 0.33 & 0.87 & nd & 1.00 \\
\hline
\end{tabular}


The ratio of $\mathrm{C}_{31} / \mathrm{C}_{31}+\mathrm{C}_{29}$ varies from 1.00 and 3.60 with mean value of 1.95 (Table 2).

The carbon preference index (CPI) of the $\mathrm{n}$-alkanes also varies with values ranging from 0.14-0.90in the oil sand samples from MBB- 0.1 and 0.01-3.80 in the oil samples from MBA-02(Table 2; Fig. 4). This indicates more maturation of OM in MBB area than the MBA area or location MBB may be closer to higher heat source.

The CPI 25-33=0.5*[( $\left.\left.\mathrm{C}_{25}-\mathrm{C}_{33}\right) /\left(\mathrm{C}_{24}-\mathrm{C}_{32}\right)\right]+\left[\left(\mathrm{C}_{25^{-}} \mathrm{C}_{33}\right) /\left(\mathrm{C}_{26}-\mathrm{C}_{34}\right)\right]$ n-alkanes can be derived from two sources i.e. vascular plant wax and fossil fuel combustion products [Ali et al., 2015]. An odd carbon preference is characteristic of oils derived from source rocks deposited in non-marine environments. In contrast, the predominance of an even numbered n-alkane preference is commonly observed in bitumen and oils derived from carbonate or evaporate rocks. This is usually characterized with CPI values that are lower than 1 . If the total even and odd numbers of paraffin are equally abundant, the value of (CPI) will be equal to 1 as generally observed in high maturity samples. This shows that the hydrocarbons are petrogenic in origin [Ali et al., 2015]. Predominance of vascular plants input to the environment usually demonstrates CPI values from 1 to 3 (Ali et al., 2015). The average CPI value of 1.61 was obtained from Ondo samples which varies 0.16 to 4.13 suggesting marginal maturity. Although this parameter is usually low in marine source rock that produce mostly low molecular weight hydrocarbons [Cooles et al., 1986; Peters and Moldowan, 1993; Eseme et al., 2002; 2006; Sengüler et al., 2008]. CPI in the $\mathrm{C}_{25}-\mathrm{C}_{31}$ range of samples from the Dahomey Basin is generally high (> 1), indicating immaturity and reflecting the contribution of wax-derived n-alkanes which form bitumen at the end of diagenesis [Hunt, 1979]. $\mathrm{Pr} / \mathrm{C}_{17}$ values range from 0.10-2.25 while $\mathrm{Ph} / \mathrm{C}_{18}$ is between 0.04-3.73 (Table 2; Fig. $4)$, these values indicate marginal to marine depositional environment. The result of $C_{31} /\left(C_{31}+C_{29}\right)(1.00-3.60)$ also supported values obtained for $\mathrm{Pr} / \mathrm{C}_{17}$ and $\mathrm{Ph} / \mathrm{C}_{18}$ depositional environment of the organic matter as dysoxic to marine environment [Pingchang et al., 2013].

\section{Acknowledgements}

Gratitude is expressed to all the Staff in the Departments of Geology, Michael Okpara University of Agriculture and University of Port Harcourt for their advice. Trican Geological Solutions, Alberta, Canada is gratefully acknowledged for the analyses of these samples.

\section{References}

[1]. Adegoke OS, Omatsola ME, Coker SJL, AOSTRA, Technical Reports, 1991, 369-3385.

[2]. Adekeye O A, Akande SO), Cont. J. Earth Sci., 2010, 5 (1), 42 - 55.

[3]. Akinmosin AA, Omosanya KO, Ikhane PR, Mosuro GO, Goodluck I, Adv. Appl. Sci. Res., 2012, 3 (4), $2078-2089$.

[4]. Akintola AI, Ikhane PR, Adeola O, Int. Res. J.Geol. Min., 2013, 3(2), 82-101.

[5]. Akinyemi LP, Odunaike RK, Fasunwon OO, CSPG/CSEG/CWLS GeoConvention Integration, 6-12 May, Calgary, Ab, Canada, 2013.

[6]. Ako BJ, In Elueze, A.A. (Ed). 2008, Nig. Min. Geosci. Soc., 2003. 61-66.

[7]. Ali S, Arash VM, Ya $\square$ mur K, Ay $\square$ e KY, Oil Shale, 2015, 32 (1), 25-41.

[8]. Bird MI, Summons RE, Gagan MK, Roksandic Z, Dowling L, Head J, Fifield LK, Cresswell RG, Johnson DP, Geochemica Cosmochim. Acta,1995, 59, 2853-2857.

[9]. Bordenove ML, Espitalie J, Leplat P, Oudin JL, Vandenbrouke M, Appl. Petrol. Geochem, 1993, $217-278$.

[10]. Bray EE, Evans ED, Geochem. Cosmochim. Acta, 1961, 22, 2-15.

[11]. Cooles GP, Mackenzie AS, Quigley TM, Org. Geochem.,1986, 10, 235-245.

[12]. Didyk BM, Simoneit BRT, Brassell SC, Eglinton G, Nature, 1978, 272, 216-222.

[13]. Eseme E, Agyingi CM, Foba-Tedo J, J. Afri. Earth Sci., 2002, 35 (4), 467-476.

[14]. Eseme E, Littke R, Agyingi CM, Petrol. Geosci., 2006,12, 69 - 74.

[15]. Espitalie J, Deroo G, Marquis F, Inst. Fr. Pet. Preprint 33578, 1985, pp.72.

[16]. Guangyou Z, Zhengjun W, Jin S, Oil Shale, 2013, 30(2), 117-135.

[17]. Head IM, Jones DM, Larter SR, Nature, 2003, 426, 344-352

[18]. Hendrix MS, Brassell SC, Carroll AR, Graham SA, Am. Assoc. Pet. Geol. Bull, 1995, 79, 929-959.

[19]. Hunt JM, Freeman, San Francisco, 1979.

[20]. Hunt JM, Second ed., W.H. Freeman and Company, New York, 1996.

[21]. Illich HA, (1983), Am. Assoc. Petrol. Geol., Bull., 1983, 67, 3385-393.

[22]. Longford FF, Blanc-Valleron MM, Am. Assoc. Petrol. Geol., Bull., 1990, 74(6), pp. 799-804.

[23]. Ndukwe VA, Ogunyinka BO, Abrakasa S, Pyrex J. Geol. Min. Res., 2015, 1, 1-6.

[24]. Obaje NG, Wehner H, Scheeder G, Abubakar MB, Jauro A, Am. Assoc. Petrol. Geol., Bull, 2004, 87,325-353.

[25]. Peters KE (1986), Am. Assoc. Petrol. Geol., Bull, 1986, 70, 318-329.

[26]. Peters KE, Moldowan JM, (1993), Prentice Hall Englewood Cliff, NJ. 1993, 363.

[27]. Peters KE, Cassa MR, Am. Assoc. Petrol. Geol., Mem. 1994, 60, pp. 93-117.

[28]. Pingchang S, Zhaojun L, Reinhard G, Yinbo X, Rong L, Baoyi L, Qingtao M, Jinjun X, Oil Shale, 2013, 30,(3), 402-418.

[29]. Sengüler I, Ayyildiz T, Onal Y, Onal M, Oil Shale, 2008, 25 (3), 359-375.

[30]. Tetede EO, Bitumen Development in Ogun State, Power Point Presentation at the Ogun State Economic Summit during the stakeholders meeting slidespages, 2006, 1-16.

[31]. Tissot BP, Welte DH, $2^{\text {nd }}$ Ed. Springer- Verlag, Berlin, Heidelberg, New York, Tokyo, 1984, pp. 699.

[32]. Tissot B, Durand B, Espitalie J, Combaz A, Am. Assoc. Petrol. Geol., Bull., 1984, 58, 499-506.

[33]. Udo RK, Univ of California Press, 1970.

[34]. Ukwuoma O, Petrol. Sci. Techn., 1999, 17, 57-65.

[35]. Van Krevalen DW, Elsevier, Amsterdam,1961, pp. 514

[36]. Waples DW, International Human Resources Development Corporation, Boston, 1985, pp. 232. 